European Review of History: Revue européenne d'histoire

\title{
Too small to be of interest, too large to grasp? Histories of the Luxembourg financial centre
}

\section{Benoît Majerus \& Benjamin Zenner}

To cite this article: Benoît Majerus \& Benjamin Zenner (2020): Too small to be of interest, too large to grasp? Histories of the Luxembourg financial centre, European Review of History: Revue européenne d'histoire, DOI: 10.1080/13507486.2020.1751587

To link to this article: https://doi.org/10.1080/13507486.2020.1751587

\section{Published online: 18 May 2020.}

Submit your article to this journal

Џ Article views: 19

Q View related articles $\sqsubset$

View Crossmark data $₫$ 


\title{
Too small to be of interest, too large to grasp? Histories of the Luxembourg financial centre
}

\author{
Benoît Majerus and Benjamin Zenner \\ Centre for Contemporary and Digital History, University of Luxembourg, Luxembourg
}

\begin{abstract}
The importance of smaller financial centres in international capitalism has recently been highlighted by a number of 'leaks'. Yet such public attention stands in contrast to the paucity of historiographical research on these relatively new centres. To this regard, Luxembourg provides an interesting case study. While identified as a 'global specialist' by the Global Financial Centres Index, the genealogy of how it came to achieve this status remains largely under-researched. This article reviews the historiography of the Luxembourg financial centre from both external perspectives - how the international social sciences and humanities have positioned the Luxembourg financial sector within the broader finance and banking context - and internal viewpoints how scholars in Luxembourg have recounted the relevant events. The Luxembourg financial centre began to appear in international historiography only in the last fifteen years. With only rare departures from general overviews and a tendency not to consult local sources, the contributions of international historians have mostly attempted to identify time frames and contextualise the particularities of its historical development. That said, a recent geographical diversification of the literature has seen the appearance of publications that demonstrate a more detailed understanding of its internal structures and links with other nerve centres of the global financial system. While a Luxembourg historiography began to develop in the late 1970s, it has often been produced to coincide with commemorative events, funded by players in the financial centre and frequently written by these same actors. While not necessarily hagiographic in approach, a lack of distance from the subject and a failure to problematise the subject has nevertheless meant that these writings are little more than factual introductions that, while useful, are limited in their historiographical depth. Furthermore, a dearth of archival research has produced a repetitive narrative based around a selection of key events and figures.
\end{abstract}

\section{ARTICLE HISTORY}

Received 28 January 2019

Accepted 1 April 2020

\section{KEYWORDS}

Luxembourg; historiography; financial centres; banking history

Over the last 10 years, public perception of the functioning of international capitalism has fundamentally changed. Revelations such as the Offshore Leaks (2013), LuxLeaks (2014), Swiss Leaks (2015) or the Panama Papers (2016), each communicated by a European alliance of media outlets, have highlighted the importance of relatively

CONTACT Benoît Majerus benoit.majerus@uni.lu E Centre for Contemporary and Digital History, University of Luxembourg, Luxembourg, 1511 Luxembourg 
young, secondary financial centres in a financial world that remains dominated by London, New York and Tokyo.

In parallel to this ever-increasing media coverage, researchers in the social sciences and humanities, be they geographers, economists, jurists, sociologists or anthropologists, have begun to study what Nicholas Shaxson calls 'treasure islands', resulting in the production of a large body of literature over the past decade. While such research frequently focuses on the last 10-15 years, Vanessa Ogle has also convincingly shown how 'archipelago capitalism' forms part of an older genealogy, often marked by traces of the former British Empire. ${ }^{1}$

While secondary financial nodes have gained centrality in contemporary accounts of global capitalism, they remain relatively understudied. Their small size often explains their lower legal regulation, fast decision-making, and therefore success in global markets: what American political scientist Peter Katzenstein calls 'flexible adaptation'. ${ }^{2}$ The diminutive magnitude of such centres is perhaps also the reason that research on the latter has been comparatively superficial relative to that on more developed financial locations. Reasons for the latter include an absence and/or weakness of universities in such places, complicated access to data (particularly for archives related to the financial world), as well as the absence of a large, and independent enough critical mass able to produce a parallel or even competitive narrative to that proposed by the actors themselves.

Since the 1960s, Luxembourg has progressively become one of the secondary financial players that 'controls and smooths the processes of global financial transactions and the trade of a dizzying array of financial products'. ${ }^{3}$ Although not operating at the level of very large financial centres, the Global Financial Centres Index (GFCI) ranks Luxembourg thirtieth among the few centres operating at the worldwide level. ${ }^{4}$ This rise has been rapid and the centre's history has only now begun to be told.

This article reviews these narratives by focusing on both external perspectives - how the international social sciences and humanities have positioned the Luxembourg financial sector within the broader finance and banking context - and internal viewpoints how scholars in Luxembourg have recounted the relevant events. The conclusion provides thoughts on directions for future work. Throughout, we use the term 'financial centre'. It is worth bearing in mind, however, that this is a heterogeneous construct: financial centres can fulfil different functions, and each has its own historicity, rationales, modus operandi and stakeholders.

\section{From the outside}

Luxembourg has recently featured prominently in the writings of several political economists on offshore financial centres (OFCs). ${ }^{5}$ These accounts have been of particular interest to historians as they rely substantially on historical arguments and assertions. Gabriel Zucman, for instance, writes that 'the Luxembourg that cofounded the [current European] union in 1957 has nothing to do with the Luxembourg of today', ${ }^{6}$ and that 'this great transformation deserves to be recounted if we wish to find a rational way to remedy it'. ${ }^{7}$ Ronan Palan, Richard Murphy and Christian Chavagneux have similarly made a point of outlining the historical development of each OFC they discuss. There are, 
however, a number of conspicuous discrepancies between the two books when it comes to the specifics of the Luxembourg centre. On the one hand, Palan et al. trace its beginnings to the $1920 \mathrm{~s},{ }^{8}$ and claim that significant portions of the domestic population have seen their living standards drastically improve due to its rapid development. ${ }^{9} \mathrm{Zucman}$, on the other hand, situates the emergence of the centre in the 1960s, ${ }^{10}$ observing that the country that has been 'cut in two', with bankers 'liv[ing] in opulence, while the rest of the population suffers an accelerated decline.' ${ }^{11}$ While the authors thus agree on the importance of a historical perspective, there are fundamental differences in terms of the specifics of the past in the Grand Duchy.

Building on this observed inconsistency, in what follows we discuss the presence of Luxembourg in international banking and financial historiography. Given the rich and diverse available literature, this review does not claim or aspire to take into account all relevant publications, but rather to ascertain how prominently Luxembourg appears in a brief survey of different types of publications. To this end, we first selected three handbooks on banking and financial history based on the breadth of their scope, the recognized expertise of their authors, and recent publication date (in an effort to provide an up-to-date picture). The books in question are: The Oxford Handbook of Banking and Financial History, ${ }^{12}$ Capitals of Capital ${ }^{13}$ and Centres and Peripheries in Banking. ${ }^{14}$ A simple query for the search term 'Luxembourg' in the bodies of these texts (i.e. excluding bibliographies and/ or endnotes) yielded the results given in Table 1:

To broaden this limited examination, we then extended our query for the term 'Luxembourg' to the online archives of three key journals of economic and financial history: The Journal of Economic History; The Economic History Review; and Financial History Review. ${ }^{15}$ Across all three, 'Luxembourg' does not appear in the title or as a

Table 1. Luxembourg in the international historiography

\begin{tabular}{lcc}
\hline Book title & $\begin{array}{c}\text { Occurrences of the term } \\
\text { 'Luxembourg' in the body text } \\
\text { (in tables and graphs) }\end{array}$ & $\begin{array}{c}\text { Number of pages with at least one } \\
\text { occurrence (total number of pages } \\
\text { of the body text) }\end{array}$ \\
\hline $\begin{array}{l}\text { Oxford Handbook of Banking and Financial } \\
\text { History }\end{array}$ & $11(2)$ & $10(504)$ \\
$\begin{array}{l}\text { Capitals of Capital } \\
\text { Centres and Peripheries in Banking }\end{array}$ & $9(0)$ & $5(287)$ \\
\hline
\end{tabular}

keyword in a single article. When switching to a simple full text search, a few hits appear, although less than 50 in total for all three journals combined. Closer inspection reveals that the latter are mostly random occurrences in book reviews or in articles unrelated to the financial centre. Luxembourg is thus virtually absent from the debate in these journals. To be clear, the point of this exercise is not to argue that historians have never discussed the Luxembourg financial centre, but is rather meant to illustrate how, especially compared to political scientists and economists, historians have thus far shown relatively little interest in the Luxembourg case. In the remainder of this section, we review the relevant international literature. 
Since the 2007/8 financial crisis, an increasing number of historians globally have turned to the study of finance, leading to thematic and geographical diversification. This shift has further stimulated a trend pre-dating the crisis, namely a growing interest in smaller and more peripheral centres. ${ }^{16}$ Indeed, while historical research of the 1980s and 1990s focused largely on centres such as London or New York (at least as far as the twentieth century was concerned), Luxembourg and other second- or third-tier centres have since begun to occupy more space in the literature. ${ }^{17}$ Perhaps unsurprisingly, however, due to their more recent emergence and smaller size, these 'younger' financial centres are treated more summarily than the older, larger 'Capitals of Capital' (Y. Cassis). That said, recent research has emphasized that these smaller or peripheral (in a geographical sense) centres or tax havens are, in fact, central to the functioning of today's global economy. ${ }^{18}$ Vanessa Ogle, for instance, argues that 'archipelago capitalism' has been '(...)a regular and integral rather than an exceptional element of twentieth-century liberal democratic capitalism'. ${ }^{19}$

With specific regard to Luxembourg, scholars have generally centred their narratives on a few landmark events, such as the passing of a 1929 law on holding companies, or the listing of the Autostrade bond (considered to be the first Eurobond issue) on the Luxembourg Stock Exchange in 1963. Yet entire decades between or after these years are markedly absent from the literature, or at best confined to a few sentences. Moreover, important aspects such as the framework provided by the Belgium-Luxembourg Economic Union (in particular the double exchange market set up in the 1950s), or the absence of a central bank in the country, are often ignored. Similarly, the domestic banking system and its connection to the growing internationally oriented financial sector tends to go unmentioned.

Beyond more general handbooks, Luxembourg does appear in a variety of thematic contexts across the literature. Its financial centre is most often cited in the context of the Euromarkets and especially Eurobonds, for which the Luxembourg Stock Exchange has become the main listing place. ${ }^{20}$ Luxembourg is frequently described as having close links with London, but the exact nature of this relationship (competition? division of labour?) and its development over time remain vague. Within this narrative, banks based in Luxembourg are sometimes described as being among the most dynamic, innovative players on these markets, particularly the branches and subsidiaries of major European banks $^{21}$ (e.g. Kredietbank Luxembourg ${ }^{22}$ ) and the European Investment Bank. ${ }^{23}$ Other times, scholars define Luxembourg as a simple 'booking centre', or a place where a large number of transactions have been recorded for tax reasons despite little real activity or decision-making. ${ }^{24}$ Yet another narrative in which Luxembourg repeatedly appears is, predictably, that of taxation. Indeed, while there has been a general lack of interest in Luxembourg on the part of historians compared to economists or legal experts, recent research based on meticulous archival exploration in several countries has furthered understandings of Luxembourg's position in a context of tax competition. ${ }^{25}$

Foreign scholars have for the most part relied almost exclusively on literature from international institutions (such as the Bank for International Settlements (BIS), European Investment Bank (EIB) and Organisation for Economic Co-operation and Development (OECD)) and central banks. Some also reference work published by stakeholders in the Luxembourg financial centre, ${ }^{26}$ often information brochures or even advertising material, limiting the depth of historical analysis. In largely ignoring the archives in Luxembourg, the international literature ultimately offers very little information on the 
domestic structures, stakeholders and particularities of the financial centre, or how they developed over time.

In summary, the Luxembourg financial centre only began to appear in international historiography in the last 15 years, and its focus has largely been on the drivers behind its development. With only rare departures from general overviews and a tendency not to consult local sources, the contributions of international historians have mostly attempted to identify time frames and contextualize the particularities of its historical development. That said, the international state of the art on Luxembourg has recently benefited from a geographical diversification of the literature. Given the international, multilingual and trans-disciplinary nature of this work, an exhaustive or comparative analysis is unfortunately well beyond the scope of the present article. However, an example of a particular finding on Liechtenstein suggests that the Luxembourg case could benefit from further study of the ways the centre is embedded in the broader inter- and transnational context.

More specifically, in the conclusion to his article on the Liechtenstein financial centre, Christoph Maria Merki convincingly shows how the latter's existence is predicated on the country's manifold connections with surrounding larger economic spaces (particularly Switzerland, but also the European Union) and, simultaneously, on its selective and deliberate distinction from them. In Merki's view, the niche that Liechtenstein has carved out for itself can only exist because it is rooted within a dense and multi-layered network of economic relations, which explains why the country is perpetually engaged in a 'delicate balance between cooperation and delimitation'. ${ }^{27}$ Exploring the ways in which Luxembourg and other offshore financial centres experience a similar tension (i.e. between its long-time economic partner Belgium, and more broadly the European Union, but also in relation to London, as the epicentre of the Euromarkets), is a research angle that has not at present been sufficiently explored. An accurate examination of the extent of these manifold connections between competing smaller financial centres and the larger global financial system requires in-depth knowledge of manifold national and international contexts, such that a collaborative approach would seem most promising.

\section{From the inside}

In parallel but separately from this international literature, a Luxembourg historiography also started to develop. Beginning in the late 1970s and the first boom period for the financial sector, an entire body of scholarly work, mostly grey literature, began to be published. These writings sometimes included historical sections that provided detailed narratives of the growth of the financial sector and the reasons for its development. An interesting corpus consists of the many dissertations on the financial centre produced by Luxembourger students in economics or law. These texts are enlightening in several ways. They are often based on first-hand information gathered in interviews, as well as draw on certain sources that are no longer available today. Some of the authors went on to become players in the financial centre, and have been influential in shaping narratives on its history. Among other examples, one of the future leaders of the Luxembourg Stock Exchange wrote his dissertation on the 'Luxembourg financial centre and international economic integration'. ${ }^{28}$ An additional analysis focusing on dissertations defended in Belgian universities uncovers several interesting related findings (Table 2 ). ${ }^{29}$ 
Table 2. Number of dissertations on the financial centre in French-speaking Belgian universities.

\begin{tabular}{cccccc}
\hline $1950 s$ & $1960 s$ & $1970 s$ & $1980 s$ & $1990 s$ & $2000 s$ \\
\hline 6 & 3 & 11 & 9 & 24 & 28 \\
\hline
\end{tabular}

Occasionally, the financial centre is contextualized within a much longer history, suggesting that it is the continuation of a series of developments that began several centuries ago. One dissertation begins, 'In 963, Sigfried acquired a strategic site', reflecting a traditional approach to Luxembourg history that attempts to give a mediaeval basis to a nation-state that took shape much later, in the second half of the nineteenth century. ${ }^{31}$ Beyond these very broad reflections on Luxembourg history, three periods are generally considered as key to the history of the financial centre:

- The 1850s. Several banks were set up in Luxembourg in the mid-nineteenth century, two of which are still operating today and have left a lasting impact on the country's financial landscape: the Banque internationale à Luxembourg (BIL) and the Caisse d'Épargne de l'État du Grand-Duché de Luxembourg (BCEE), both founded in 1856.

- The 1929 law on financial holding companies. Inspired by legislation in several Swiss cantons, this act set up a favourable tax regime for holdings and encouraged the development of offshore industry. ${ }^{32}$ It is cited in virtually all the research that includes a historical component. The studies also emphasize that this regulation, together with the creation of the stock exchange that same year did not, however, have the intended effect, due both to the economic crisis of 1929 and the Second World War. Indeed, the deglobalization experienced by the Western world during this time put an end to efforts to create an international financial centre.

- The 1960s and 1970s. Economists and legal experts agree that the true boom period for the financial centre began in these years. Those who see investment funds as its basis tend to favour the 1960s (as the number of funds increased from 1161 in 1961 to 2309 in $1970^{33}$ ), while those who focus on banks opt to point to the 1970s (as the number of banks rose from 37 in 1970 to 109 in 1980). ${ }^{34}$ In addition to this chronological dispute, another open question is why exactly the financial centre started to succeed. Some argue that it began to prosper thanks to events outside Luxembourg, particularly the Interest Equalization Tax enacted in the United States in 1963, which raised the cost of borrowing dollars for non-residents, together with the Kouponsteuer, a withholding tax introduced in Germany in 1965 to limit the influx of foreign capital. Others claim instead that it was the active efforts of the Luxembourg government to devise a suitable regulatory framework for these new circumstances that provided the impetus for the centre's growth. ${ }^{35}$

This three-point chronological timeline, which was further solidified in the early 1980s, has rarely been challenged. Although over the past decade, several studies in the social sciences and humanities, from economics to geography, have significantly emphasized the history of the financial centre. Scholars such André Bauler and Gérard Trausch, for example, have both adopted an economic history approach, wherein the financial centre 
is presented as a virtually 'natural' development for a nation-state whose economy developed through the exercise of 'national sovereignty' from the nineteenth century onwards, whether this be the clause prohibiting exportation for the steel industry in the 1880s (Verhüttungsklausel), the commercialization of a public service concession by a private group (the Compagnie Luxembourgeoise de Radiodiffusion) in the 1930s, or the development of tax niches for the financial centre. Yet while the state plays a central role in André Bauler's analysis, the stakeholders are not clearly delineated. Who were the men (and women) behind it, what groups and tensions have shaped its development? Nor does he address an aspect that sets Luxembourg apart, namely that of conferring responsibilities normally attributed to the state to private companies, such as the diplomatic role of the steel company ARBED. ${ }^{36}$ Gérard Trausch, who similarly begins in the nineteenth century to explain the roots of the Luxembourg economy, proposes a narrative that partly opposes that of Bauler. He presents the financial centre as a product of external factors, especially the decisions made by the United States (the interest equalization tax) and Germany (increase in reserves by the Bundesbank). In his words: 'The gradual expansion of the service sector in the Luxembourg economy is not rooted in the proactive action of various Luxembourg governments; it is the result of legal/regulatory provisions abroad. ${ }^{37}$ Gérard Trausch is also critical of the position occupied by the financial sector in Luxembourg, contemplating the potential risks to the democratic functioning of a society that is increasingly dominated by financialization. While adopting a less historically based approach, a team of researchers working with economist Patrice Pieretti has similarly emphasized the role of external factors in the growth of the industry, without, however, ignoring the 'somewhat proactive impetus that created conditions conducive to the emergence of a competitive banking and financial centre'. ${ }^{38}$ Unlike Gérard Trausch, these authors do not provide their views on broader questions relating to the societal consequences of a dominance of the financial sector.

More recently, geographers working in Luxembourg have also begun to study the financial industry. Using a 'historically informed' ${ }^{39}$ approach, these scholars have positioned, to a greater extent than that seen in economic research, Luxembourg within a globalized geography of finance. While neither systematic nor explicitly stated, such work often has a comparative dimension relative to other financial centres. Cities such as Singapore, Geneva and Frankfurt, and countries such as Ireland and the Netherlands are regularly used to provide a broader context for understanding Luxembourg's development. In contrast to other studies in the social sciences and humanities, which are mainly confined to the national setting, such research often uses an international perspective. One of the major lines of inquiry within this literature revolves around the question of why Luxembourg emerged from the crisis of the late 2000 s relatively unscathed. Without denying the continued existence of tax benefits, the geographers have proposed another model, that of an 'agglomeration economy'. More specifically, they suggest that, since at least the 2000s, the Luxembourg financial centre has had a financial ecology strong enough to provide the endogenous conditions needed for its existence: a flexible workforce, recognized specialization in a variety of fields within a broad ecosystem, and so on. ${ }^{40}$ Based on grey and secondary literature and interviews with players in the financial centre, this is undoubtedly one the most systematic attempts made thus far in the Luxembourg social sciences and humanities to analyse the financial centre from the inside, while simultaneously placing it in a context of international research. 
More broadly, an examination of research conducted on the financial centre, in disciplines as diverse as economics, law, socio-linguists and geography, highlights the extent to which the narrative of the history of the financial centre has been shaped by these different scholars. Indeed, more so than other phenomena, such as the history of migration or the history of the steel industry after 1945, this history has largely been written by non-historians. ${ }^{41}$ This is partly explained by the scarcity of historical work on finance and banking in Luxembourg. Economic history is the poor relation of Luxembourger historiography; only the history of the steel industry has enjoyed systematic, on-going attention over the past 30 years. ${ }^{42}$

Historical monographs based on archival research are relatively rare. A few banks have been examined in more detail, ${ }^{43}$ and there exist several biographies on key figures, ${ }^{44}$ but these studies are mostly anecdotal. For its $75^{\text {th }}$ anniversary, the Indosuez bank, whose forerunner, La Luxembourgeoise, continues to operate as an insurer on the market, asked the well-known historian Gilbert Trausch to trace the history of the financial centre. In response, Trausch, together with Marianne De Vreese, wrote a text that continues, despite signs of being out-dated, to represent a key reference work on the subject. For these scholars, 'the financial centre is [...] a foreign body grafted onto the trunk of Luxembourg'. ${ }^{45}$ They viewed the financial centre as alien to Luxembourg society, albeit admitting that it had undoubtedly benefited from several measures adopted by the country. Twenty years later, another study attempted to revitalize the genre by conducting approximately 20 interviews with key players in the financial centre. While this more recent work does not fundamentally challenge the chronologies outlined earlier, it does explore in further depth the various phases experienced by the financial centre, especially the crisis of the early 1980s when the Euromarket temporarily dried up following a default by Mexico and then other Third World countries. ${ }^{46}$

While informative, such studies are also problematic, particularly in three areas. First, they tend to be written in a commemorative context, which can give rise to a certain degree of bias. In his book on the BIL, Christian Calmes depicts the history of the bank as one of great men working for the country:

Throughout this long journey stretching over two centuries and marked by significant and hazardous changes to the political and economic regime, the Bank was led by remarkable men on many occasions [....] And thus we can trace a long series of men who would give much to the Bank and, in so doing, to the economy of the country.

Calmes also sees the banking system as an economic model for the entire nation, noting that: 'Independently of its political ambitions, any country - however small - should have an economic ambition of the sort that seems to be driving the banking sector in our era. ${ }^{47}$ This narrative, which at times borders on hagiography, seems characteristic of commemorative works that often lack critical distance or an analytical approach, even if providing a useful factual and chronological framework. Second, members of the financial sector have frequently been involved in the drafting process. ${ }^{48}$ While such participation may offer advantages, such as facilitating access to sources or players, ${ }^{49}$ it once again raises questions concerning sufficient distance from the topic. Finally, in both the books by Christian Calmes and Trausch and De Vreese, there is an absence of a referencing model that would enable readers to consult to the sources used. In addition, a lack of archival research produces a repetitive narrative based around a selection of key events 
and figures. To date, academic historiography has contributed only tentative reflections relative to a more finely grained chronology of the sector, ${ }^{50}$ together with some exploratory research on conceptual visions of the financial centre. ${ }^{51}$ In conjuncture with this scarcity of scholarly work, recent scandals (LuxLeaks, the Panama Papers and others) have given rise to a historically slanted journalism, revealing both the diversity of players involved and the close link between political and financial elites. ${ }^{52}$

While historiographical work based on a systematic analysis of sources is rare, the financial centre has appeared on a regular basis in more general histories of Luxembourg published over the past 40 years. Yet while the centre's central position in the Luxembourg economy makes its inclusion imperative, the absence of a detailed historiography often reduces these narratives to a few generalities.

One of the first of these broad accounts to include an economic history was written by Gilbert Trausch in 1975. ${ }^{53}$ The historian offers the following explanations for the growth of the financial centre: 'a favourable regime for holding companies, tax exemption on foreign loan issues, the easy admission of these loans to the Luxembourg Stock Exchange [...] an atmosphere of political and social stability'. ${ }^{54}$ In a latter volume, Trausch underlines the important role of the financial centre, seen as one of the 'keys to Luxembourg's success'. The author then remarks on debate arising in the 1990s over whether ' ... Luxembourg [is] in the process of moving from steel monolithism to financial monolithism', but also defends the centre, observing: 'Keen to ensure its good reputation, Luxembourg adopted stringent legislation against money laundering and financial fraud. ${ }^{55}$

In most of the texts of this genre, the narrative revolves around two topics. First, the authors consider the endogenous and exogenous reasons for the development of the financial centre and their respective impacts. Second, they speculate on its consequences for Luxembourg society, in some cases taking a stance relative to the criticism levelled at the centre. For Michel Pauly, the growth of the financial centre was not the result of proactive government policy 'aimed at compensating losses caused by the steel crisis' but rather 'a question of chance'. ${ }^{56}$ Emile Haag adopts a similar argument: 'It has often been claimed that Luxembourg sought to attract foreign banks by passing extremely favourable fiscal legislation. In fact, external reasons and regulations, not domestic ones, triggered the beginnings of the country's financial centre. ${ }^{57}$ Jean-Marie Kreins claims instead that the success of the financial centre is essentially a result of what he euphemistically refers to as 'national particularities' ${ }^{58}$

\section{Conclusion}

This historiographical overview aims to pave the way for a history of the Luxembourg financial centre within a European and global context. We conclude by reflecting on directions for future work. Before doing so, however, it is important to note that the recent archiving law adopted by the Luxembourg parliament will significantly hinder historical research and make accessing archives on the financial and banking centre much more difficult. ${ }^{59}$

The history of the financial centre is not just one of banks. While Luxembourg's historiography mostly consists of a small number of institutional monographs about banks and the general development of this sector, a history of banks should go beyond this economic and institutional narrative, exploring both the social history of the actors 
involved (whose roles are much more diverse than the generic term 'banker' might suggest) ${ }^{60}$ and important geographical and urban dimensions. With regard to the latter, of particular significance are the transformations of Luxembourg City and its surrounding area (the destruction of the nineteenth-century buildings on the Boulevard Royal and the development of the Kirchberg Plateau are but the most visible elements), migrations (from the malleable labour class of cross-border workers, to the most senior directors), and, of course, politics and the interconnections between banking and governmental circles. Furthermore, the financial sector is composed of many other players different from banks and bankers. One group that played a key role in the 1960s and has hitherto been entirely excluded from the historical narrative (as well as that of other disciplines within humanities and social sciences) is (business) lawyers. Yet these professionals provide a fundamental mediation service between banks (most often foreign) and Luxembourg's (political) elites. ${ }^{61}$ Over time, many other activities also have developed alongside and around banking, ranging from the insurance sector ${ }^{62}$ and fiduciary management $^{63}$ to IT services, consultancy firms ${ }^{64}$ and cleaning companies. Considering all these players would provide a more comprehensive view of the impact of the financial centre on Luxembourg.

The financial centre's past also forms part of a broader history that goes beyond the borders of Luxembourg. To this regard, two aspects are of particular interest for further exploration.

The first is a particular narrative of European history that has become increasingly prevalent over the past decade, and which divides the later twentieth century into two parts. The first period stretches from the late 1940s to the early 1970s, and is characterized by strong economic growth and faith in (social) progress, commonly known as the 'Trente Glorieuses' (The Glorious Thirty). The second period, whose length is rarely defined, instead sees a decline or stagnation in economic activity and a loss of societal values/utopias, a period classified as 'after the boom' by Anselm Doering-Manteuffel and Lutz Raphael (2008). ${ }^{65}$ A greater understanding of the development of the financial sector and the history of Luxembourg, among other countries, could shed new light on this narrative. The post-Bretton Woods period, while sometimes described as one of the reasons for the decline, then paved the way for the development of a globalized financial industry that proved to be a particularly dynamic sector, and which saw countries such as Luxembourg begin a phase of strong growth. Luxembourger historian Paul Zahlen observes that although the Grand Duchy's gross domestic product (GDP) grew less than the European average during the post-war boom, the country experienced particularly high growth in the 1980s and 1990s, leading him to label this period the 'Vingt Splendides' (The Splendid Twenty). ${ }^{66}$

The second aspect concerns the recent geographical diversification of financial and banking historiography. Humanities scholars have increasingly turned their attention away from well-studied centres such as London, Paris or Switzerland, to focus on 'peripheral' locations in the international financial system. Yet as the Luxembourg example shows, integrating such locations into a narrative can prove challenging. That said, whether it be Panama, Liechtenstein or the Bahamas, these small countries have successfully demonstrated a 'flexible adaptation' to the system that has progressively taken shape after Bretton Woods. ${ }^{67}$ The 'division of labour' between second-tier or peripheral financial centres, as well as the niche strategies they employ in a context of 
mutual competition, begs further historical exploration. Moreover, international cooperation between researchers working on these countries seems all the more vital given that many themes and issues are comparable between cases. At present, however, there remains a considerable gap between the growing importance of centres such as Luxembourg and the weakness of (historical) research, explained in part by a lack of relevant academic traditions and consequent weak connections to international research, commemorative rather than historical work, and difficult access to archives.

\section{Notes}

1. Ogle, "Archipelago Capitalism.”

2. Ingebritsen, "Katzenstein's Legacy 25 Years After."

3. Dörry, "Strategic Nodes in Investment Fund Global Production Networks."

4. Le Luxembourg is considered a 'global specialist' by the Global Financial Centres Index 25 (2019).

5. The two examples discussed here are: Palan, Murphy, and Chavagneux, Tax Havens and Zucman, The Hidden Wealth of Nations.

6. Zucman, The Hidden Wealth of Nations, 85.

7. Ibid., 86.

8. Ronen, Murphy, and Chavagneux, Tax Havens, 107, 119.

9. Ibid., 119.

10. Zucman, The Hidden Wealth of Nations, 85-6.

11. Ibid., 91.

12. Cassis, Grossman, and Schenk, The Oxford Banking and Financial History.

13. Cassis, Capitals of Capital.

14. Cottrell, Lange, and Olsson, Centres and Peripheries

15. This choice of publications follows John D. Turner, who cites the latter as leading journals in the field. See Turner, "Financial History and Financial Economics."

16. Cottrell, Lange, and Olsson, Centres and Peripheries; Schenk, "Banking Crises."

17. In addition to Cassis, Capitals of Capital, see also Merki, Europas Finanzzentren.

18. Palan, Murphy, and Chavagneux, Tax Havens, 3.

19. Ogle, "Archipelago Capitalism," 1433.

20. The author who perhaps most prominently mentions Luxembourg is Chris O’Malley in Bonds without Borders.

21. Bussière and Cassis, London and Paris as International Financial Centres, 196.

22. O'Malley, Bonds without Borders.

23. Bussière, Dumoulin, and Willaert, The Bank of the European Union.

24. The distinction between different types of centre was addressed in an influential article by Y. S. Park from 1982: Park, "The Economics of Offshore Financial Centers."

25. Farquet, La défense du paradis fiscal suisse.

26. A typical example is: Société de la Bourse, A Guide to 50 Years of Eurobonds in Luxembourg.

27. Merki, "Der Finanzplatz Liechtenstein: Zürichs attraktive Außenstelle." The original quote is 'heikle[n] Balance zwischen Kooperation und Abgrenzung,' 188.

28. Maquil, "La place financière de Luxembourg."

29. We chose to examine French-speaking Belgian universities both because their limited number facilitates bibliographical research via the library catalogues, and because a significant number of Luxembourger students attended French-speaking Belgian universities during this period: Statistiques historiques, 535.

30. Leemans, "La place financière," 10.

31. Peporté et al., Inventing Luxembourg, 33.

32. Thomas, "Naissance d'un paradis fiscal."

33. Ley, "Les sociétés holding au Grand-Duché de Luxembourg," 31. 
34. Neis, "La place financière du Grand-Duché de Luxembourg," 35.

35. Eich, "La législation holding."

36. Bauler, Les fruits de la souveraineté nationale; Harmel, Souvenirs, 119.

37. Trausch, La société luxembourgeoise, 77.

38. Pieretti, Bourgain, and Courtin, La place financière de Luxembourge, 12.

39. Dörry, “The Role of Elites," 21.

40. Walther, Schultz, and Dörry, "Specialised International Financial Centres and their Crisis Resilience."

41. Graf and Priemel, "Zeitgeschichte in der Welt der Sozialwissenschaften."

42. Zahlen, "Entre quantification, personnalisation et autoportrait."

43. Calmes, Une banque raconte; Trausch, Belgique - Luxembourg.

44. More so for his role in the Werner Plan than as Minister of Finance (1953-64, 1969-74), see: Danescu, "The Werner Report."

45. Trausch and de Vreese, Luxembourg et les banques, 10.

46. Moyse, Meiers, and Maquil, Les artisans de l'industrie financière.

47. Calmes, Une banque raconte son histoire, 10.

48. For example: Association luxembourgeoise des fonds d'investissement, ALFI: 20th Anniversary; Association luxembourgeoise des fonds d'investissement, ALFI: Association luxembourgeoise des fonds d'investissement 1988-1998.

49. Ibid., p. 7 explains that Michel Maquil, former Director of the Luxembourg Stock Exchange, 'managed to persuade several people to share their account'.

50. Lehners, "The History of Banks in Luxembourg"; Franz, "Der Finanzplatz Luxemburg als Ergebnis wirtschaftlichen Bedarfs, politischen Willens und europäischer Integration."

51. Auxenfants, "Paradis fiscal"; Auxenfants, "Place financière."

52. Thomas, "Naissance d'un paradis fiscal"; Thomas, "Les confrères."

53. An earlier 'History of Luxembourg' published in 1972 barely mentions the history of the steel industry; that of the financial centre does not appear at all. The narrative finishes with the end of the Second World War in 1945. Herchen et al., Manuel d'histoire nationale.

54. Trausch, Le Luxembourg à l'époque contemporaine, 186.

55. Trausch, Histoire du Luxembourg, 263-4.

56. Pauly, Histoire du Luxembourg, 131.

57. Haag, The Rise of Luxembourg, 229.

58. Kreins, Histoire du Luxembourg, 112.

59. Under pressure from the Ministry of Finance, any archives containing tax data have been made inaccessible for 100 years. Pauly, "Das Steuergeheimnis gilt auf ewig."

60. For example, the collective bargaining agreement for the banking sector in the 1990s includes professions as varied as 'supervisory staff, 'cleaner', 'kitchen help' and so on: Thomas, "Dussmann ante portas."

61. Thomas, "Les confrères." See also Dezalay, Marchands de droit.

62. Zahlen, La Luxembourgeoise.

63. On this subject see the very interesting autobiography of Hamilius, Luxemburg im Wandel der Zeiten.

64. Deloitte \& Touche, 50 ans.

65. Doering-Manteuffel and Raphael, Nach dem Boom; Niall Ferguson uses the expression 'shock of the global' to refer to the developments of the 1970s. See Ferguson et al., The Shock of the Global.

66. Zahlen, "Le Luxembourg 1960-2010," 1.

67. The Liechtenstein case was partly addressed in discussions in the early twenty-first century concerning the participation of Switzerland and Liechtenstein in the spoliation of European Jews during the Second World War. A committee of historians published six studies detailing the role of Liechtenstein, two of which are directly linked to the history of the financial sector: Ernst \& Young AG and Karlen, Untersuchung zu nachrichtenlosen Vermögenswerten bei liechtensteinischen Banken in der NS-Zeit; Lussy and Lopez, Finanzbeziehungen Liechtensteins. For other countries, the historiography is virtually absent. 


\section{Disclosure statement}

No potential conflict of interest was reported by the author.

\section{Notes on contributors}

Benoît Majerus is Associate Professor for European History at the University of Luxembourg and is currently working on a history of the financial place of Luxembourg after 1945.

Benjamin Zenner holds a Master's degree in Contemporary European history from the University of Luxembourg. He is currently writing a $\mathrm{PhD}$ dissertation at the Universities of Luxembourg and Lausanne on the history of banking regulation in Luxembourg, 1945-84.

\section{Bibliography}

Association luxembourgeoise des fonds d'investissement. ALFI: Association luxembourgeoise des fonds d'investissement = Luxembourg Investment Fund Association: 1988-1998. Luxembourg: ALFI, 1998.

Association luxembourgeoise des fonds d'investissement. ALFI: 20th Anniversary Jubilee Report: 1988-2008. Luxembourg: Association of the Luxembourg Fund Industry, 2008.

Auxenfants, Marc. "Paradis Fiscal." In Lieux de Mémoire au Luxembourg II: Jeux d'échelles, edited by Sonja Kmec and Pit Peporté, 85-90. Luxembourg: Edition Saint-Paul, 2012.

Auxenfants, Marc. "Place Financière." In Lieux de Mémoire au Luxembourg II: Jeux d'échelles, edited by Sonja Kmec and Pit Peporté, 79-84. Luxembourg: Edition Saint-Paul, 2012.

Bauler, André. Les fruits de la souveraineté nationale: essais sur le développement de l'économie luxembourgeoise de 1815 à 1999: une vue institutionnelle. Luxembourg: Caisse Centrale Raiffeisen, 2001.

Bussière, Eric, and Youssef Cassis. London and Paris as International Financial Centres in the Twentieth Century. Oxford: Oxford University Press, 2005. http://site.ebrary.com/id/ 10303097.

Bussière, Eric, Michel Dumoulin, and Emilie Willaert, eds. The Bank of the European Union: the EIB, 1958-2008. Luxembourg: European Investment Bank, 2008.

Calmes, Christian. Une banque raconte son histoire: histoire de la Banque Internationale: 18561981. Luxembourg: Saint-Paul, 1981.

Cassis, Youssef. Capitals of Capital: the Rise and Fall of International Financial Centres, 1780-2009. Cambridge: Cambridge University Press, 2010.

Cassis, Youssef, Richard S. Grossman, and Catherine R. Schenk, eds. The Oxford Banking and Financial History. Oxford: Oxford University Press, 2016.

Cottrell, Philip, Even Lange, and Ulf Olsson, eds. Centres and Peripheries in Banking: The Historical Development of Financial Markets. Aldershot: Ashgate, 2007.

Danescu, Elena. "The Werner Report and the Financial Crisis during the 1970s." In Euro Changes: European Responses to Economics and Social Changes. From the 1970s to the New Millennium, edited by Paolo Tedeschi and René Leboutte, 68-78. Brussels: Peter Lang, 2018.

Deloitte \& Touche. 50 Ans Au Service de l'économie Luxembourgeoise. Luxembourg: Editions Guy Binsfeld, 2000.

Dezalay, Yves. Marchands de droit: la restructuration de l'ordre juridique international par les multinationales du droit. Paris: Fayard, 2011.

Doering-Manteuffel, Anselm, and Lutz Raphael. Nach dem Boom: Perspektiven auf die Zeitgeschichte seit 1970. Göttingen: Vandenhoeck \& Ruprecht, 2008.

Dörry, Sabine. "Strategic Nodes in Investment Fund Global Production Networks: The Example of the Financial Centre Luxembourg." Journal of Economic Geography 15, no. 4 (July 1, 2015): 797814. doi:10.1093/jeg/lbu031. 
Dörry, Sabine. "The Role of Elites in the Co-Evolution of International Financial Markets and Financial Centres: The Case of Luxembourg." Competition \& Change 20, no. 1 (2016): 2136.

Eich, Eric. "La législation holding et son impact sur l'économie luxembourgeoise." Mémoire de licence, UCL, 1979.

Ernst \& Young AG, and Stefan Karlen. Untersuchung zu nachrichtenlosen Vermögenswerten bei liechtensteinischen Banken in der NS-Zeit. Versicherungen in Liechtenstein zur Zeit des Nationalsozialismus. Zürich: Chronos, 2005.

Émile Haag, The rise of Luxembourg. From independence to success. Luxembourg: Saint-Paul, 2015.

Farquet, Christophe. La défense du paradis fiscal suisse avant la Seconde Guerre mondiale: une histoire internationale. Neuchâtel: Editions Alphil, 2016.

Ferguson, Niall, Charles S. Maier, Erez Manela, and Daniel J. Sargent. The Shock of the Global: The 1970s in Perspective. Cambridge, MA: Harvard University Press, 2010.

Franz, Norbert. "Der Finanzplatz Luxemburg als Ergebnis wirtschaftlichen Bedarfs, politischen Willens und europäischer Integration." In Europas Finanzzentren. Geschichte und Bedeutung im 20. Jahrhundert, edited by Christoph Maria Merki, 149-165. Frankfurt am Main: Campus Verlag, 2005.

The Global Financial Centres Index 25, 2019.

Graf, Rüdiger, and Kim C. Priemel. "Zeitgeschichte in der Welt der Sozialwissenschaften. Legitimität und Originalität einer Disziplin.” Vierteljahrshefte für Zeitgeschichte 59, no. 4 (2011): 479-508.

Gilbert Trausch et Marianne de Vreese, Luxembourg et les banques: de la révolution industrielle au 7 centre financier mondial. Luxembourg: Banque Indosuez, 1995.

Haag, Émile. The rise of Luxembourg. From independence to success. Luxembourg: Saint-Paul, 2015.

Hamilius, Jean. Luxemburg im Wandel der Zeiten: Erinnerungen (1927-2014). Luxembourg: Binsfeld, 2014.

Harmel, Xavier. Souvenirs très personnels d"un banquier à Luxembourg. S.l.: XHarmel, 2002.

Herchen, Arthur, Nicolas Margue, and Joseph Meyers. Manuel d'histoire nationale. 9th ed. Luxembourg: Linden, 1972.

Ingebritsen, Christine. "Katzenstein's Legacy 25 Years After: Small States in World Markets." European Political Science 9 (September 1, 2010): 359-364. doi:10.1057/eps.2010.23.

Kreins, Jean-Marie. Histoire du Luxembourg: des origines à nos jours. 4th ed. Paris: Presses Universitaires de France, 2007.

Leemans, Patrick. "La Place Financière de Luxembourg à l'horizon 1992.” Mémoire de licence, ULB, 1988.

Lehners, Jean-Paul. "The History of Banks in Luxembourg." In Handbook on the History of European Banks, edited by Manfred Pohl and Sabine Freitag, 675-715. Brookfield: Edward Elgar Publishing, 1994.

Ley, Jean. "Les sociétés holding au Grand-Duché de Luxembourg dans le contexte national et communautaire." Mémoire de licence, UCL, 1988.

Lussy, Hanspeter, and Rodriguez Lopez. Finanzbeziehungen Liechtensteins zur Zeit des Nationalsozialismus. Zürich: Chronos, 2005.

Maquil, Michel. "La place financière de Luxembourg face à l"intégration économique international." UCL, 1974.

Merki, Christoph Maria. Europas Finanzzentren: Geschichte und Bedeutung im 20. Jahrhundert. Frankfurt am Main: Campus Verlag, 2005.

Merki, Christoph Maria. “Der Finanzplatz Liechtenstein: Zürichs attraktive Außenstelle.” In Europas Finanzzentren. Geschichte und Bedeutung im 20. Jahrhundert, edited by Christoph Maria Merki, 167-195. Frankfurt am Main: Campus Verlag, 2005.

Moyse, Laurent, Claude Meiers, and Michel Maquil. Les artisans de l'industrie financière. Luxembourg: Editions Saint-Paul, 2014.

Neis, Simone. "La place financière du Grand-Duché de Luxembourg: Son importance et son fonctionnement.” Mémoire de licence, ULB, 1980. 
Ogle, Vanessa. "Archipelago Capitalism: Tax Havens, Offshore Money, and the State, 1950s1970s." American Historical Review 122, no. 5 (December 2017): 1431-1458.

O’Malley, Chris. Bonds without Borders: A History of the Eurobond Market. Chichester: John Wiley \& Sons, 2015.

Palan, Ronen, Richard Murphy, and Christian Chavagneux. Tax Havens: How Globalization Really Works. Ithaca, NY: Cornell University Press, 2010.

Park, Y. S. "The Economics of Offshore Financial Centers." Columbia Journal of World Business 17, no. 4 (1982): 31-35.

Pauly, Michel. Histoire du Luxembourg. Bruxelles: PUB, 2013.

Pauly, Michel. “Das Steuergeheimnis gilt auf ewig.” Forum 382 (2018): 14-15.

Péporté, Pit, Sonja Kmec, Benoît Majerus, and Michel Margue. Inventing Luxembourg: Representations of the Past, Space and Language from the Nineteenth to the Twenty-First Century. Leiden: Brill, 2010.

Pieretti, Patrice, Arnaud Bourgain, and Philippe Courtin. La place financière de Luxembourg: Analyse des Sources de ses avantages compétitifs et de sa dynamique. Brussels: De Boeck, 2007.

Schenk, Catherine R. "Banking Crises and the Evolution of the Regulatory Framework in Hong Kong 1945-1970.” Australian Economic History Review 43, no. 2 (July 2003): 140-154. doi:10.1111/1467-8446.t01-1-00047.

Société de la Bourse. A Guide to 50 Years of Eurobonds in Luxembourg. Luxembourg: Société de la Bourse, 2013.

Statistiques historiques: 1839-1989. Luxembourg: STATEC, 1990.

Thomas, Bernard. "Les confrères.” D’Lëtzebuerger Land, July 2016.

Thomas, Bernard. “Naissance d'un paradis fiscal.” D'Lëtzebuerger Land, August 2016, 10-11.

Thomas, Bernard. "Dussmann ante portas.” D’Lëtzebuerger Land, July 2018.

Trausch, Gilbert. Le Luxembourg à l'époque contemporaine, du partage de 1839 à nos Jours. Manuel d'histoire Luxembourgeoise 4. Luxembourg: Editions Bourg-Bourger, 1975.

Trausch, Gilbert, ed. Belgique - Luxembourg: les relations belgo-luxembourgeoises et la Banque générale du Luxembourg (1919-1994). Imprimerie Centrale. Luxembourg, 1995.

Trausch, Gilbert, ed. Histoire du Luxembourg: Le destin européen d'un petit pays. Histoire des territoires de France et d'Europe. Toulouse: Privat, 2002.

Trausch, Gilbert et de Vreese, Marianne. Luxembourg et les banques: de la révolution industrielle au 7 centre financier mondial. Luxembourg: Banque Indosuez, 1995.

Trausch, Gérard. La société luxembourgeoise face à ses problèmes économiques et sociaux. Cahier Économique 119. Luxembourg: Statec, 2015.

Turner, John D. "Financial History and Financial Economics." In The Oxford Handbook of Banking and Financial History, edited by Youssef Cassis, Richard S. Grossman, and Catherine R. Schenk, 41-61. Oxford: OUP, 2016.

Walther, Olivier, Christian Schulz, and Sabine Dörry. "Specialised International Financial Centres and Their Crisis Resilience: The Case of Luxembourg." Geographische Zeitschrift 99, no. 2/3 (2011): 123-142.

Zahlen, Paul. "Le Luxembourg 1960-2010. L'évolution économique globale du Luxembourg sur la longue durée.” 50 Ans - Statec, 2013.

Zahlen, Paul. "Entre quantification, personnalisation et autoportrait. L'historiographie économique au Luxembourg." D'Lëtzebuerger Land, November 9, 2018.

Zahlen, Paul. La Luxembourgeoise: 100 Ans d'assurance Privée Au Grand-Duché. Luxembourg: La Luxembourgeoise, forthcoming.

Zucman, Gabriel. Hidden Wealth of Nations: the Scourge of Tax Havens. Chicago: University Of Chicago Press, 2016. 